\section{A arte de construir pontes}

André BOTELHO. O Brasil e os dias: Estadonação, modernismo e rotina intelectual. Bauru, Edusc, 2005. 255 páginas.

\section{Gabriela Nunes Ferreira}

A temática da construção do Estado-nação no Brasil é das mais ricas e tem sido objeto de bons trabalhos, sob perspectivas e ângulos diversos, no campo dessa ampla área de estudo que podemos chamar de "Pensamento social e político brasileiro".

O Brasil e os dias é um brilhante exemplo de como explorar essa temática em toda a sua riqueza mediante, principalmente, a construção de pontes metodológicas e analíticas capazes de relacionar aspectos muitas vezes pensados de maneira unilateral ou disjuntiva. O livro é oriundo da tese de doutorado defendida em 2002 na Unicamp; o autor é hoje professor e pesquisador da Universidade Federal do Rio de Janeiro e assina também outros trabalhos de qualidade no campo do pensamento social brasileiro - como, por exemplo, seu livro anterior: Aprendizado do Brasil: a nação em busca de seus portadores sociais (Campinas, Editora da Unicamp, 2002).

O tema do Estado-nação, por si só, já é um convite à construção de pontes, pois incita o esforço intelectual de procurar as inter-relações entre os seus dois conceitos constitutivos: Estado e nação - remetendo-nos também à relação entre outros pares conceituais como cultura e política, solidariedade social e autoridade pública. Em seu livro, André Botelho explora essas múltiplas relações sem se furtar ao desafio de examinar a fundo as bases de pontes já construídas anteriormente pela bibliografia e, mais ainda, edificar outras novas e promissoras.

A primeira ponte construída no livro tem caráter metodológico, e diz respeito à abordagem dada ao estudo das idéias do autor/ator estudado, o modernista carioca Ronald de Carvalho. Tratase, afirma André Botelho, de "encontrar uma síntese" entre os partidos metodológicos textualista e contextualista na análise das idéias. Inspirado em Quentin Skinner, o autor parte da seguinte ques- tão: o que Ronald de Carvalho estava fazendo ao escrever seus artigos, conferências e ensaios entre os anos de 1910 e 1930? Na busca da resposta a essa questão, enfrenta o duplo desafio de interpretar a dimensão de sentido dos textos de Carvalho para, ao mesmo tempo, resgatar os seus efeitos discursivos e sociais mais amplos.

Completando o movimento característico da sociologia do conhecimento, que põe ênfase na construção social da idéias, o programa proposto por Botelho é "buscar a forma pela qual as idéias constituem-se em forças sociais reflexivas", ou seja, participam da construção do social - da construção social das idéias à construção do social. Daí a importância atribuída no trabalho ao tema da "rotina intelectual", processo pelo qual práticas e valores inscritos, por exemplo, nas "interpretações do Brasil" elaboradas no ć́rculo restrito dos intelectuais ganham o mundo, transformam-se em senso comum, plasmam a realidade.

Entendendo o Estado-nação não como uma forma social acabada, mas como um processo, continuamente renovado, de adequação entre "nação" e "Estado", Botelho examina um momento privilegiado desse processo: o da formação do pacto ideológico, social e político que ganhará corpo institucional no Estado forte e centralizado construído sob Getúlio Vargas nos anos de 1930.

O papel dos intelectuais na construção do delicado equilíbrio entre "solidariedade social" e "autoridade pública", entre cultura e política, é abordado a partir da figura de Ronald de Carvalho, figura em si mesma bastante propícia à descoberta de novas e ricas pontes. Primeiro, porque Ronald de Carvalho foi ao mesmo tempo um autor - que, como sustenta Botelho, contribuiu para a rotinização de valores e idéias elitistas, antiliberais, antidemocráticas - e um ator político diretamente dedicado às tarefas do Estado, com posição de destaque no Itamaraty e no governo Vargas. A sua atuação no Itamaraty, diga-se de passagem, especialmente no momento estratégico da reorganização do poder aberto com a Revolução de 1930, chama a atenção para a ponte existente entre política interna e política externa.

Segundo, porque sua formação e atuação intelectuais deram-se nos quadros do Modernismo, o que faz dele um autor privilegiado para entender e explorar "as inter-relações entre o 
tema da renovação cultural, de que se fizeram porta-vozes os modernistas em geral, e o tema da organização social e política brasileira, de que se ocuparam, mais explicitamente, os críticos conservadores e autoritários da Primeira República liberal e oligárquica [...]" (p. 28). A crítica ao transplante de ideários exógenos à sociedade brasileira, por exemplo, insistentemente repetida naquele período, aplicava-se tanto ao campo cultural e estético como ao social e político. Mas como bem observa Botelho, não é comum a análise desses dois temas de forma integrada.

Ronald de Carvalho, diz o autor, articula fortemente a idéia de "cultura" à de "nação", dandolhe com isso um sentido profundamente político. A cultura deveria ser, para o modernista carioca, fonte de uma nova forma de solidariedade social, de tipo nacional, a ser forjada para dar base e legitimidade a um Estado forte e centralizador. A idéia de nação, tal como desenvolvida por Ronald de Carvalho, é discutida no livro tendo como referência duas concepções de nação muitas vezes analisadas como antitéticas: uma concepção "política”, originada da Revolução Francesa e baseada na igualdade e na soberania popular como fontes de legitimidade, e uma "cultural", originada do Romantismo alemão, enfatizando os traços histórico-culturais comuns como fonte de coesão. André Botelho recusa tal tratamento disjuntivo dos dois conceitos de nação, argumentando que ele obscurece as relações e as tensões existentes entre ambos. É sobre essa ponte conceitual que as idéias de Ronald de Carvalho de nação e cultura são apresentadas: de um lado, a recusa à idéia romântica "essencialista" de nação, chamando a atenção para o caráter mais "voluntarista" da cultura e da própria nação como realidades a serem forjadas. De outro lado, a mesma crítica romântica aos valores universais de igualdade e direitos como base da construção nacional.

Outra ponte iluminada pela análise da trajetória e da obra de Ronald de Carvalho é aquela entre o tradicional e o moderno, entre continuidade e ruptura. O poeta e ensaísta é, de fato, figura emblemática do processo de modernização con-servadora então vivido pelo Brasil. A renovação cultural e a reconstrução do Estado-nação não deveriam, segundo ele, implicar uma reordenação da organização social brasileira, antes pelo contrário: a expe- riência das elites dirigentes tradicionais e o papel positivo da família patriarcal para a estabilidade social $^{1}$ deveriam ser valorizados e promovidos.

O próprio movimento modernista, afirma Botelho, tinha como central a idéia de ruptura, mas não deixava de conter, em vários aspectos, uma forte dimensão de continuidade. O Modernismo brasileiro, e este é mais um dos pontos interessantes do trabalho, é tratado aqui não como bloco monolítico, mas explorado em suas nuanças e diversidade interna.

André Botelho parece às vezes muito preocupado em justificar a escolha, como objeto de pesquisa, de um autor tido como de "segunda linha”, e o faz reforçando a tese de que a obra de Ronald de Carvalho teria contribuído para a rotinização de valores e práticas antiliberais e autoritárias. De qualquer modo, pode-se dizer que a escolha da figura de Ronald de Carvalho como porta de entrada para pensar o papel dos intelectuais na construção do Estado-nação se justifica e é particularmente feliz, antes de tudo, justamente porque sua trajetória e produção intelectuais se prestam ao estabelecimento e à exploração de múltiplas e variadas pontes, capazes de trazer à luz a complexidade e as nuanças desse processo.

A última ponte que o livro constrói é entre passado e presente. Qual a importância de se debruçar sobre o tema da construção do Estadonação exatamente num momento em que esse conceito parece entrar em crise, abalado pelas marés da globalização? Para onde quer que caminhemos, é fundamental reter o legado cultural e político do Estado-nação brasileiro até porque, como lembra Botelho, a forma como se deu historicamente a construção da cidadania afeta necessariamente o seu exercício no presente.

\section{Notas}

1 Nesse ponto, André Botelho nota que Ronald de Carvalho assemelha-se mais a Gilberto Freyre do que a Oliveira Vianna, do qual era ideologicamente mais próximo. A interpenetração entre público e privado na construção nacional, idéia que agradava a Ronald de Carvalho, era de fato repudiada por Oliveira Vianna. 
GABRIELA NUNES FERREIRA é professora de Ciência Política na Universidade Federal de São Paulo (Unifesp/Guarulhos). E-mail: gabinf@uol.com.br. 